\title{
ARENA FUTSAL DAN SEPAKBOLA GAYA BEBAS
}

\author{
Albert Halim ${ }^{1)}$, Budi Adelar Sukada ${ }^{2)}$ \\ 1) Program Studi S1 Arsitektur, Fakultas Teknik, Universitas Tarumanagara, albertfrenz39@gmail.com \\ 2) Program Studi S1 Arsitektur, Fakultas Teknik, Universitas Tarumanagara, budisukada@yahoo.com
}

\begin{abstract}
Abstrak
Olahraga merupakan bagian yang tidak bisa dilepaskan dari kehidupan masyarakat Indonesia. Selain untuk menyehatkan tubuh, olahraga juga banyak manfaat dan fungsi lain. Antara lain sebagai penghilang stress, sumber penghasilan, penunjuk strata sosial, dan lain-lain. Kota Jakarta sebagai ibukota dan merupakan kota terbesar di Indonesia tentunya sudah menjadi pusat perkembangan olahraga. Perkembangan sepakbola di Jakarta yang sangat pesat saat ini, juga diikuti dengan perkembangan olahraga lain namun masih menggunakan teknik dasar sepakbola dalam permainannya, yaitu olahraga Futsal. Saat ini Kota Jakarta memiliki satu kawasan pusat olahraga yang memiliki berbagai fasilitas cabang olahraga. Dari Antusias warga Kota Jakarta terhadap olahraga seperti futsal dan sepakbola gaya bebas dan sejenisnya yang sangat tinggi namun belum adanya tempat atau wadah bagi masyarakat untuk menyalurkan hobinya dalam bidang olahraga tersebut dengan mencoba mengangkat suatu kawasan tematik yang menggabungkan antara olahraga dan rekreasi yang nantinya kawasan ini dapat menjadi wadah menyalurkan bakat dan prestasi dalam bidang olahraga juga menjadi taman terbuka bagi masyarakat kota Jakarta.
\end{abstract}

Kata kunci: Bakat, Olahraga, Prestasi, Rekreasi.

\begin{abstract}
Sport is a part that can not be removed from public life Indonesia. In addition to nourish the body, it also sports many benefits and other functions. Among other things as a source of income, stress relievers, bookmark social strata, and others. The city of Jakarta as the capital and largest city in Indonesia would have been the center of the development of the sport. The development of soccer in Jakarta that very rapidly at the moment, also followed with the development of other sports but still using the basic techniques of soccer in his game, namely sports Futsal. Jakarta currently has one district sports center that has a variety of sports facilities. From Enthusiastic townspeople Jakarta against sports such as futsal and football freestyle and the like are very high but not yet the existence of the place or the container for the public to channel his hobby in sports to try to lift a thematic area that combines sport and recreation later this area can become a container of talent and achievement in the field of sports also became a garden open to the public.
\end{abstract}

Keywords: achievements, recreation, sports, talents.

\section{PENDAHULUAN}

Olahraga sudah tidak lagi menjadi identitas untuk seorang atlet, namun olahraga telah menjadi salah satu gaya hidup masyarakat Indonesia, baik hanya sekedar jogging sampai kepada olahraga yang cenderung memerlukan kegiatan fisik yang cukup berat, seperti sepakbola, basket dan olahraga fisik lainnya.Olahraga futsal menjadi salah satu olahraga yang sangat akrab di telinga masyarakat kota Jakarta. Olahraga ini dimainkan baik oleh para penggemar sepakbola, khususnya futsal, orang-orang yang sudah cukup berumur, masyarakat usia produktif, anak-anak, bahkan perempuan di kota Jakarta pun juga turut memainkan olahraga ini. Kawasan Arena Futsal dan Sepakbola Gaya Bebas merupakan suatu sarana publik yang direncanakan sebagai fasilitas olahraga. Oleh karena itu penekanan pada citra kawasan sangat penting untuk menggambarkan kawasan tersebut merupakan suatu kawasan olahraga yang bertemakan olahraga sepakbola. Perancangan proyek Arena Futsal dan Sepakbola Gaya Bebas di kota Jakarta diharapkan menjadi sebuah kawasan olahraga, rekreasi dan aktifitas 
lainnya. Ada banyak cara untuk berolahraga, tetapi proyek Arena Futsal dan Sepakbola Gaya Bebas ini menawarkan sesuatu yang berbeda. Berolahraga, berwisata dan juga jalin solidaritas.

\title{
2. METODE
}

Metode yang akan digunakan adalah pengumpulan data dan survei. Pengumpulan data dilakukan dengan melihat keadaan lingkungan sekitar tapak yang memungkinkan orang untuk bermain disana dan juga dari zonasi.

\author{
Gambar 1. Zonasi Tapak Terpilih \\ Sumber: https://smartcity.jakarta.go.id/
}

Zonasi yang terpilih adalah zona S5 yang merupakan zona pelayanan umum dan sosial khusus olahraga. Dengan melihat kecocokan ini dan daerah yang terpilih, maka saya akhirnya memilih tapak tersebut.

Metode selanjutnya adalah analisis kebutuhan ruang dan standar-standar berdasarkan FIFA (Federation of International Football Association) dan Neufert.

Dari hasil metode tersebut, perencanaan dan perancangan bangunan dibuat. Hasilnya dibangunlah Arena Futsal dan Sepakbola Gaya Bebas di daerah Pulo Gadung yang banyak peminat futsalnya.

\section{Gambar 2. Survei Tapak Terpilih}

Sumber: Dokumentasi Pribadi

\section{DISKUSI DAN HASIL}

Konsep bangunan ini berawal dari bentukan massa bangunan yang berupa persegi panjang yang merupakan lapangan sepak bola. Bentukan-bentukan massa yang berbentuk 4 persegi panjang ini dihaluskan bentukannya sehingga masing-masing bentukan sisi-sisi pinggirannya menyerupai oval.

Arena ini dibagi menjadi 2 bagian yaitu area indoor dan area outdoor. Area indoor diletakkan di tengah yang memiliki 3 fungsi yaitu publik yang berada di depan dan tengah, privat yang berada di kiri dan kanan, dan servis yang berada di belakang bangunan. Sedangkan area outdoor memiliki fungsi privat karena merupakan tempat olahraga dan latihan untuk 
atlet. Sirkulasi utama tersebut merupakan sirkulasi pejalan kaki, mobil, dan servis seperti mobil barang atau mobil pemadam kebakaran. Sirkulasi di dalam kawasan menerapkan konsep menyebar dan mengelilingi kawasan untuk menjangkau seluruh bangunan yang tersebar di dalam kawasan.

Gambar 3. Zoning Tapak

Sumber: Dokumentasi Pribadi

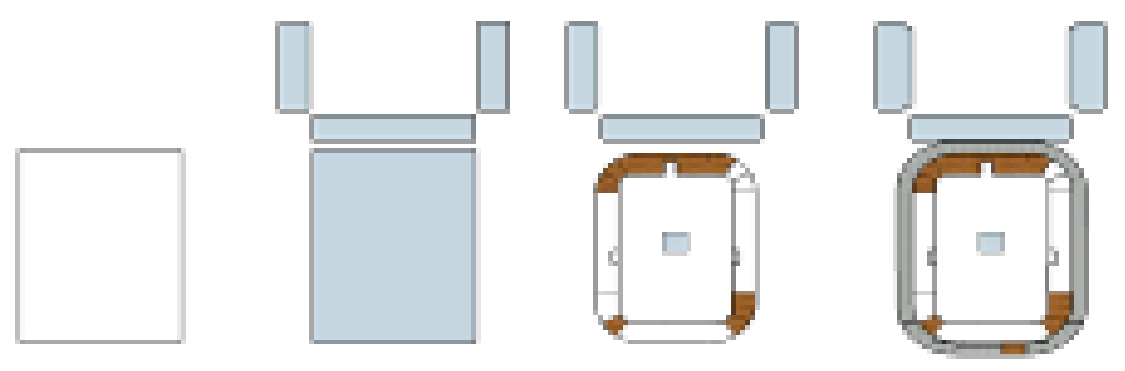

Gambar 4. Proses Gubahan Massa

Sumber: Dokumentasi Pribadi

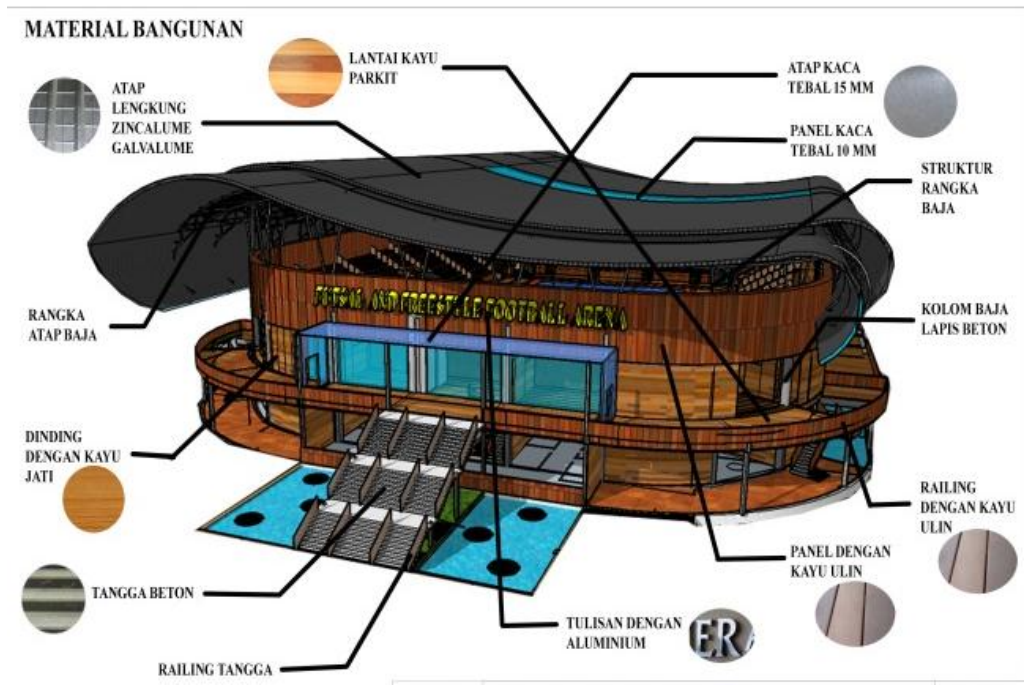

Gambar 5. Material Bangunan Sumber: Dokumentasi Pribadi 
Arena yang dijadikan sebagai pertandingan skala regional ini pun dibangun dengan menggunakan material kayu jati dan kayu parkit. Penggunaan elemen kayu ini bertujuan untuk menghidupkan suasana natural sesuai dengan konsep yang diterapkan.

Atap bangunan ini menggunakan atap lengkung Zincalume Galvalume ${ }^{1}$. Hal ini bertujuan untuk menarik perhatian pengunjung karena bentuknya berbeda dari yang lainnya. Bentukannya seperti bentuk atap yang besar dan kuat yang menerapkan konsep dari sepakbola itu sendiri, dengan ditopang oleh tiang-tiang kokoh yang besar sebagai lambing dari kerjasama.

Bangunan ini terdiri dari 3 lantai yaitu lantai dasar sebagai tempat makan bersama dan tempat atlet latihan. Lantai dua sebagai tempat lobby utama, area menonton bagi pengunjung, serta tempat atlit berganti baju dan bersiap-siap. Lantai 3 digunakan sebagai ruang komentator dan ruang VIP dengan menggunakan akses lift yang langsung menuju ke sana. Uniknya ada perbedaan lantai antara atlit dengan pengunjung, sehingga pengunjung tidak bisa langsung berhadapan dengan atlit. Dapat dilihat juga di gambar 8. Jalur evakuasi arena ini ada 6 akses pintu keluar.

\author{
Gambar 6. Detail Tribun Bangunan \\ Sumber: Dokumentasi Pribadi
}

Gambar 7. Eksploded Denah Bangunan

Sumber: Dokumentasi Pribadi 


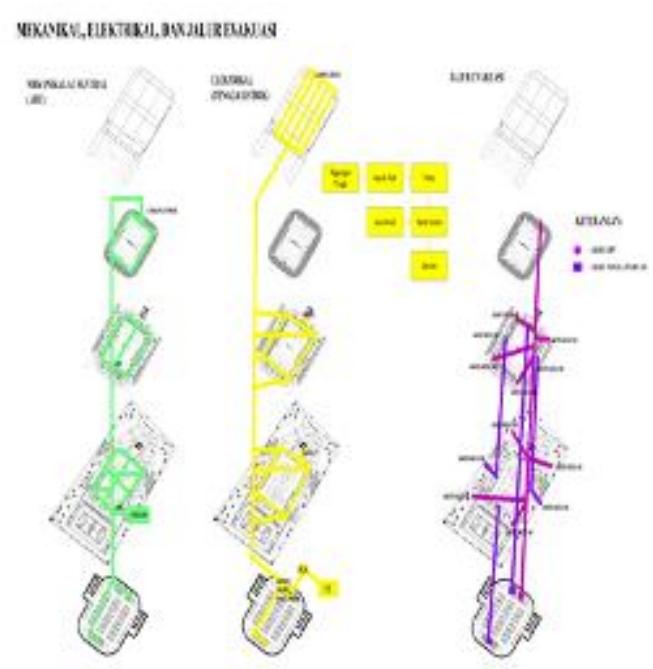

Gambar 8. Jalur Listrik, AC, dan Evakuasi Sumber: Dokumentasi Pribadi

Gambar 9. Potongan Perspektif

Sumber: Dokumentasi Pribadi

Arena ini dapat menampung orang hingga 2500 orang. Di potongan perspektif dapat terlihat perbedaan antara area indoor yang digunakan sebagai pertandingan utama, dengan area outdoor sebagai tempat latihan bagi atlit dan juga pertunjukan freestyle football atau sepakbola gaya bebas.

Jika dilihat dengan menggunakan system $x$-ray atau tembus pandang, maka dapat terlihat jalur evakuasi yaitu 5 tangga darurat yang terletak di sisi kiri, kanan, dan belakang bangunan, sedangkan di bagian depan menggunakan tangga besar. Tangga utama inilah yang mengantar pengunjung untuk langsung menuju lobby utama, sehingga tidak dibuat bingung saat ingin masuk ke arena pertandingan. Sedangkan atlit turun di sisi kanan dan kiri bangunan dengan menggunakan mobil yang langsung disediakan drop off nya di depan lobby tersebut.

Penggunaan material dapat dilihat di gambar 11, bahwa struktur utama yang digunakan yaitu baja. Hal ini dikarenakan untuk menahan beban pengunjung hingga 2.500 orang dan juga 
atap bentang lebar yang sangat besar tersebut. Rangka baja yang menahan atap lengkung tersebut berbentuk $V$ seperti tangan yang menopang beban dari unsur kerjasama.

Gambar 10. Zoning Vertikal

Sumber: Dokumentasi Pribadi

Gambar 11. Aksonometri Struktur

Sumber: Dokumentasi Pribadi

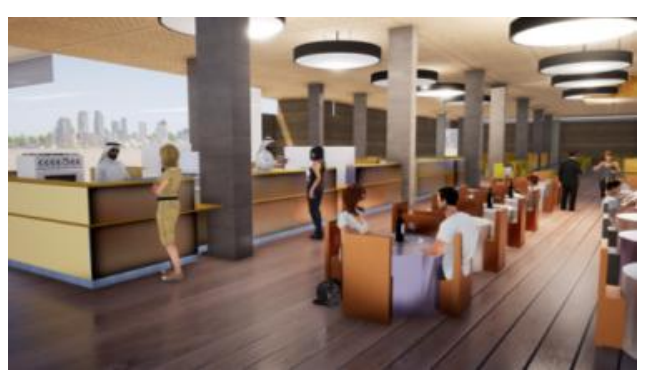

Gambar 12. Perspektif Interior GOR

Sumber: Dokumentasi Pribadi 


\section{Gambar 13. Perspektif Eksterior GOR}

Sumber: Dokumentasi Pribadi

\section{KESIMPULAN DAN SARAN}

Adapun kesimpulan yang dapat diambil dari perancangan kawasan Arena Futsal dan Sepakbola Gaya Bebas ini, sebagai berikut :

- Arena Futsal dan Sepakbola Gaya Bebas merupakan suatu kawasan yang diperuntukan sebagai sarana olahraga dengan tema sepakbola dan ruang terbuka sebagai fungsi lainnya.

- Kawasan Arena Futsal dan Sepakbola Gaya Bebas memiliki beberapa massa bangunan yang masing-masing memiliki fungsi yang berbeda sesuai dengan aktifitas dan kegiatan di dalamnya.

- Kawasan Arena Futsal dan Sepakbola Gaya Bebas dirancang sebagai tempat yang representatif bagi kegiatan olahraga khususnya futsal dan sepakbola gaya bebas yang saat ini belum dimiliki oleh Kota Jakarta.

\section{REFERENSI}

https://helmihidayat007.wordpress.com/2008/12/22/perkembangan-futsal-di-indonesia/ https://media.neliti.com/media/publications/189308-ID-mini-football-square-di-kota-

pontianak.pdf

https://segulungperkamen.wordpress.com/tag/perkembangan-sepak-bola-indonesia/ https://darisjati.wordpress.com/2011/07/06/profil-ssb-bina-taruna-rawamangun/ http://dwi-rezki-uzumaga.blogspo.com/2013/06/hubungan-olahraga-dengan-kesehatan.html Neufert, Ernst and Peter. (2000). Architect's Data Third Edition. Wiley-Blackwell: United States Specht, Jan. 2014. Architectural Tourism: Building for Urban Travel Destination, Gabler Verlag. HIm. 18

https://id.wikipedia.org/wiki/Piala_Dunia_Sepak_Bola_Pantai_FIFA 